\section{Why become complicated?}

SiR-P. R. Sheldon (Nature 347, 704; 25 October 1990) asks why simple organisms such as bacteria do not develop the same complexity as other less numerous lineages, even though their prolific numbers should allow more variations to develop. The simple answer is that eukaryotic organisms have more DNA than prokaryotes and so more potential for development, although this does not explain why prokaryotic DNA is restricted.

One possibility is that the mitochondrion, by providing an organelle for the efficient production of energy-related proteins, allowed the eukaryotic cell to develop more complex control mechanisms - and hence a more complex genome - than a prokaryotic cell. This would also explain how a chance combination of two prokaryotic cells could be selected as a useful symbiont (L. Margolis, Symbiosis in Cell Evolution, Freeman, 1981).

In prokaryotes, the energy-producing proteins are manufactured alongside lessused proteins and are subject to the same manufacturing constraints. In eukaryotes, the mitochondrion contains only a little DNA which it uses to manufacture proteins using ribosomes and a reduced number of transfer RNAs. Hence the overheads for protein production are a minimum and the speed of protein production should be a maximum. The main eukaryotic cell is then freed from making these proteins and has the opportunity to specialize in making a wider range of proteins in a slower, more controlled, fashion.

Which protein manufacturing system most closely resembled that used by the early prokaryotes: the cell or the mitochondrion?

\section{Park Lane,}

Wembley HA9 7RZ, UK

SIR-The answer to Sheldon's question, I believe, is that only eukaryotic cells can evolve complex morphology. It is well known that all prokaryotic organisms are unicellular and morphologically simple, whereas even unicellular eukaryotes are morph slogically more complicated. One of the reasons for this difference is mitosis and meiosis (which occur in eukaryotes but not in prokaryotes), and another is the presence of endoplasmic reticulum in eukaryotes, on which are enzymes needed for morphogenesis and multicellular organization.

But the shortfall in this explanation is that it fails to deal with the question of what are the needed enzymes and how do they work - what, in other words, is the biochemical basis of morphogenesis? We can expand this question: what is the biochemical basis of cellular irritability in all its manifestations? This is a fundamental question, for which present-day molecular biologists have no answer.

BENJAMIN LOWENHAUPT

Biology Department

Allegheny College,

Meadville, Pennsylvania 16335, USA

\section{Cohort of genes}

SIR - I was pleased that Nature $(\mathbf{3 4 7}, 221$; 1990) highlighted the fact that confidentiality, in particular matters of life and health insurance, will complicate attempts to sequence the human genome in ways that should be faced. What the report did not address was a much more fundamental and equally urgent issue of how we are going to discover what effect specific common genetic variations have on health and development. The report simply states that "with good planning and much hard work there will be a comprehensive listing of all functioning human genes and information about the ways in which they can vary either harmlessly or otherwise, from one individual to another". There is, however, a conspicuous lack of forward planning of research that will have the power and precision to determine whether a given genetic variation is harmless or otherwise, and, if otherwise, in what circumstances it is harmful. The author assumes (probably correctly) that the overwhelming proportion of genetic variations will be harmless, and no doubt also assumes that clinical research will easily sort out those that are harmful. In fact, this will not be easy, particularly with respect to which DNA sequence polymorphisms confer susceptibility or resistance to common multifactorial disease.

The growing tide of anxiety about being singled out for genetic tests, in the absence of clear clinical indication, will, I predict, make the analysis of controls in conventional case control studies problematic, especially in childhood where additional ethical constraints operate. Furthermore, case control design, although often costeffective, is unsuitable for disclosing positively protective alleles (not just the absence of risk aileles); just the type of genetic variation for which there would be positive selection pressure.

What is needed is a population cohort study in which a cell line on each individual provides a renewable source of DNA for analysis and where it is accepted by everyone involved that unspecified and strictly confidential research on factors influencing health and development will be performed. Such a study, the Avon Longitudinal Study of Pregnancy and Childhood has just been launched, but, as yet, the blood collection next spring and the generation of 22,000 cell lines from cord and maternal bloods are without funding. This unique opportunity to make sense of the genetic variation revealed by the Human Genome Project will be virtually impossible to recreate.

What will be the use of a comprehensive listing of DNA sequence polymorphisms within all functioning human genes, if we cannot discover what they mean in terms of health and development? It will be impossible to sustain support for the Human Genome Project if this aspect is not addressed soon and comprehensively.

Mothercare Department of

Marcus E. Pembrey

Paediatric Genetics,

Institute of Child Health,

University of London,

London WC1N 1EH, UK

\section{Art for art's sake}

SIR-Your admiring caption to a colour picture of a fine feather tabard from ancient Peru (Nature 347, 425; 1990), currently for sale by a London art dealer, noticed that "primitive" art is gaining in status and value. Thomas Gibson Fine Art, vendors of the tabard, assure me that their items were legally exported from Peru and that they can supply a purchaser with a written statement to that effect. But the market in antiquities as art objects inflicts devastation on the archaeology of many countries, notably Peru. Site after site has been quarried by clandestine diggers, wrecking all archaeological context and stratigraphy in quest of saleable 'goodies', which are smuggled abroad and leave the possibility of archaeological understanding in ruin. European looting of the heritage of native Americans go:s back centuries, but the commercial trade is larger and the effect more dreadful now than ever (T. Kaiser J. Field Arch. 17, $205-10 ; 1990)$. Every pillaged site in the Peruvian desert is a loss to science and to the people of Peru whose history it held. The same goes for those many other places - from the Greek Cycladic islands to the desert southwestern United States - whose ancient artefacts chance to catch the modern fancy.

Many of the antiquities that circulate in the art trade are looted; and the promotion of their elegant value is the engine of price that fuels the looters and smuggiers - as surely as a good market in the developed countries for tropical hardwood finances the cutting of the rain forests.

You call the tabard 'primitive' art, and the appropriate Oxford English Dictionary definition of primitive is "simple, rude, or rough". The tabard is not primitive. It simply comes from an artistic tradition outside the Western experience.

Antiquity,

CHRISTOPHER CHIPPINDALE

Hills Road

Cambridge CB2 1PG, UK 